\title{
INTEGRATED WATERSHED MANAGEMENT PROGRAMME AT GUNJALA VILLAGE - A CASE STUDY
}

\author{
P.Sudha Rani ${ }^{1}$, Nalla Naresh ${ }^{2}$ \\ ${ }^{I}$ M.Tech (Water and Envtl Technology), P.hD (Environmental Science), Osmania University \\ ${ }^{2}$ M.Sc, (Envtl.Sc), M.Tech( Envtl Management) JNTUH.
}

\begin{abstract}
Integrated watershed management programme was launched in Tamsi mandal of gunjala village by using 'Four water Concept'. Case study included Questionnaire survey from farmers living in that village, and continuous study over a period of two years. Tamsi village is a tribal village and drought area with very less rainfall. Total project area is 4566 Hac, Project Cost Rs. 547.92 Lakhs. The sanctioned area of Gunjala micro watershed is 710 Hac with a outlay of Rs. 85.20 Lakhs. Out of which the total expenditure incurred was Rs.39.12 Lakhs and constructed structures were LBS, RFDs, PTs, CDs and Plantation. Over two year period, it was observed that, 2 years of period the ground water has been improved in this village and three Bore wells are drilled and they are successful, even during peak summer they could meet their day today activities.
\end{abstract}

The farmer Jadhav Uttam has an additional income of Rs. 17600 per Acre in cotton and Rs. 6300 per Acre in Red Gram. The farmer Gnan Singh had an additional income of Rs. 17600 per Acre in cotton and Rs. 5,250 per Acre in Red Gram. The farmer Amber Singh had an additional income of Rs. 13200 per Acre in cotton and Rs. 3,500 per Acre in Red Gram. In the same way, others farmers were also able to generate the benefits from the construction of water storage structures. Total Additional income generated for Seven farmers was Rs. 6, 31000/- in 2011-2012 Cropping Season with construction of Check Dams of Rs.3,24000/an additional average income per Acre to the farmer is of Rs. 22,500/- and a series of 8 Nos. check dams are constructed on single $3^{\text {rd }}$ order stream which flows Across the 6 Grama Panchayats from ridge to valley. There are 90 farmers cultivating 168 Acre of land who are benefited by getting an additional income of Rs.37,80,000/-.

Keywords: Four water Concept, micro watershed, LBS, RFDs, PTs, CDs and Plantation $* * *$

\section{INTRODUCTION}

The Integrated Watershed Management Programme (IWMP) is launched with an aim to restore the ecological balance by harnessing, conserving and developing degraded natural resources such as water, soil,vegetative cover and create sustainable livelihoods for asset less people.

"Four Waters Concept" is an innovative participatory technology in watershed development which encourages the farmers in Watershed Committees to formulate the works and execute the same with their own initiatives, without the help of engineers and scientists. This Technology is named by the authors as "Four Waters Concept" since this is evolved by integrating the "Four Waters", viz. rain water, soil moisture, ground water and surface water. The advantages of this technology are that with the same cost, it is possible to increase the benefits three time more, and increase the recharge to ground water ten times more than earlier. Cost effective works have been introduced in this concept and can be implemented with better results. The works proposed in this technology can be executed by the farmers without the medium contractors. The works can be executed by the watersheds committees, without the usual preparation of plans and estimates by the field engineers. These works are very simple and mostly consist of earthwork excavation. There is no cement - based work.

\section{OBJECTIVE}

The major objective of the IWMP programme is to improve the ground water level by constructing the water harvesting structure like Mini Percolation tank, Percolation tank and Check dams. To sum up, the following are the important works that were executed, as per the technologies developed in the Integrated four Waters concept, That maximum benefits were derived in the watershed. This technology is generally applicable to the forest areas also. With the objective to increase the Ground water level, the following work has been carried out.

The study included Questionnaire survey from the villagers( 7 farmers ) of Tamsi mandal, gunjala village and complete study of that area for a period of two years before and after the construction of check dam and other water storage structures. 


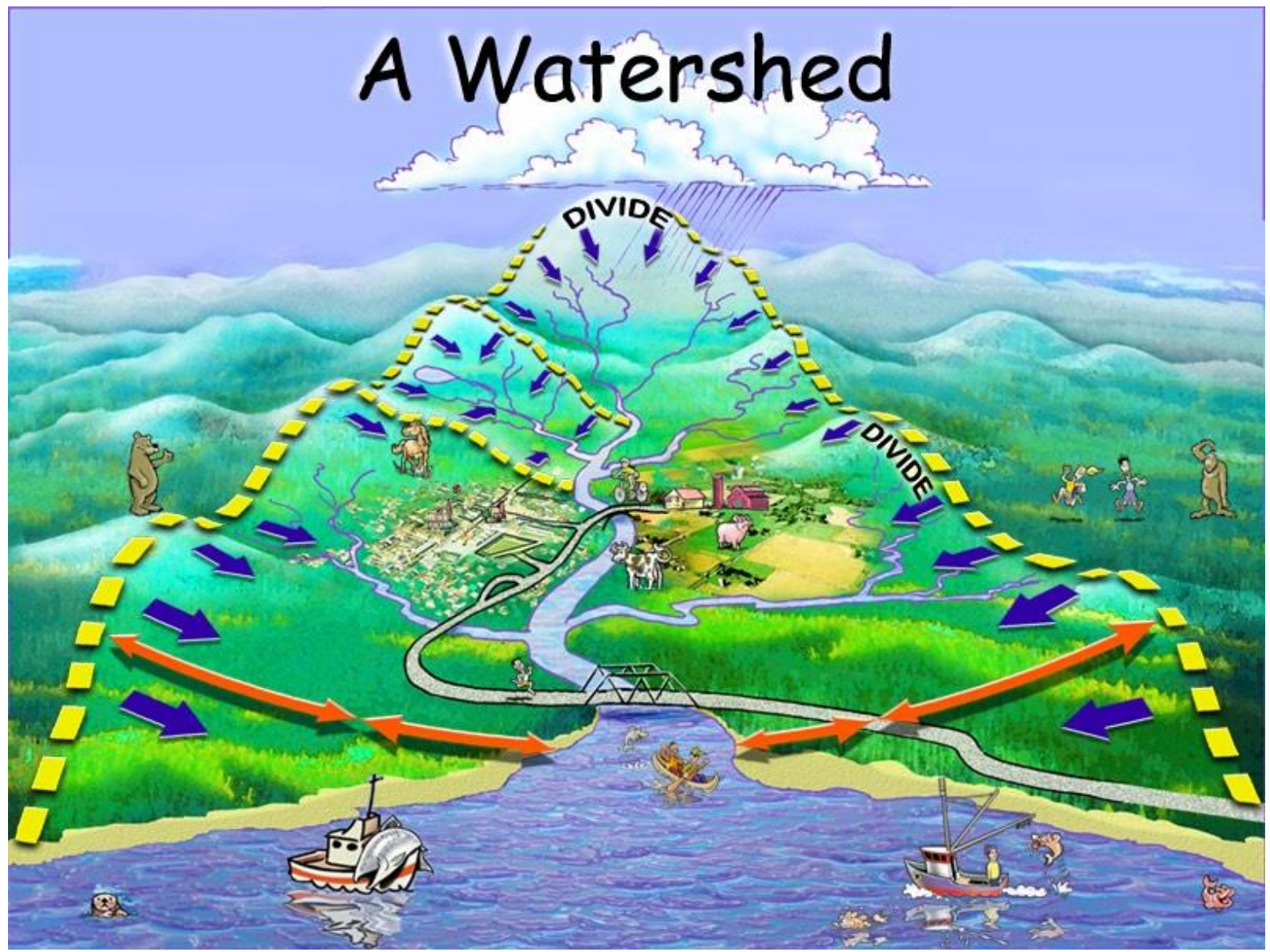

INTEGRATED WATERSHED MANAGEMENT PROGRAMME

\section{THE SUCCESS STORY OF CHECK DAM IN THE INTEGRATED WATERSHED MANAGEMENT PROGRAMEE (IWMP) IN DHANORA PROJECT (2009-10) OF GUNJALA MICRO WATERSHED IN TAMSI MANDAL OF ADILABAD DISTRICT}

NAME OF THE PROJECT: BATCH

DHANORA

NAME OF THE MANDAL: NAME OF THE MICRO WATERHSED TOTAL PROJECT AREA:

TOTAL PROJECT COST :

LAKHS.

TOTAL MICRO WATERSHED AREA: TOTAL OUT LAYOF MWS: EXPENDITURE OF MWS: LONGITUTE OF CD LATITUTE 2009-10 TAMSI GUNJALA $4566 \mathrm{Hac}$ 547.92

$710 \mathrm{Hac}$ 85.20 LAKHS. 42.98 LAKHS $78^{0} 25^{\prime} 27$ $19^{0} 47^{\prime} 57^{\prime}$,

The Gunjala trible village of Tamsi mandal is a drought area, covered with red gravel soil the availability of ground water is below $300-400 \mathrm{fts}$. Though the rainfall is $1100 \mathrm{~mm}$ the major problem of this village is scarcity of ground water, and there is only a single third order stream which flows Across the village from ridge to valley. Due to non availability of water harvesting structures, the rain water is to run off.

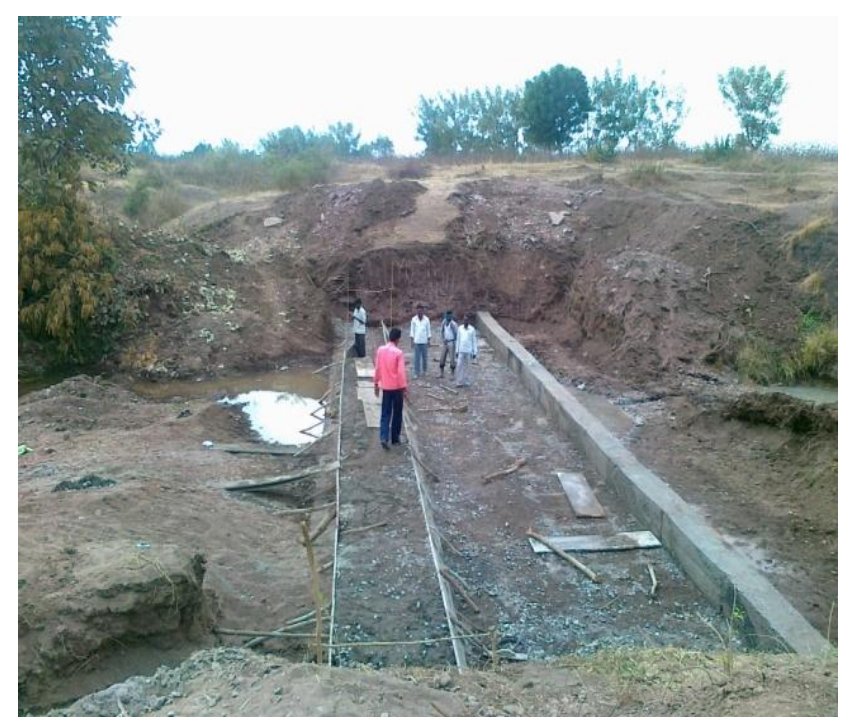

The Gunjala trible village of Tamsi mandal is a drought area, covered with red gravel soil the availability of ground water is below $300-400 \mathrm{fts}$. Though the rainfall is $1100 \mathrm{~mm}$ the major problem of this village is scarcity of ground water, and there is only a single third order stream which flows Across the village from ridge to valley. Due to non availability of water harvesting structures, the rain water is to run off. They used to get water from the nearby Bheempur village for daily use. The villagers several time 
brought to the notice of the public representatives, they have drilled the bore wells in different locations. But the bores are failed, due to scarcity of ground water.

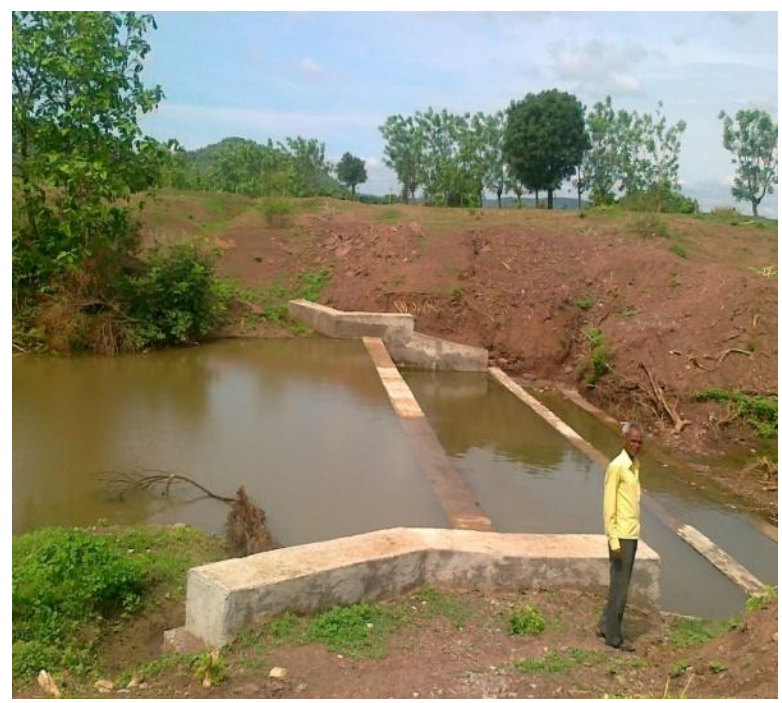

In the year 2009-10 Government of India has launched The Integrated Watershed Management Programme (IWMP) with an aim to restore the ecological balance by harnessing, conserving and developing degraded natural resources such as water, soil, vegetative cover and create sustainable livelihoods for asset less.

Under IWMP 2009-10, (9) Mega watersheds have been sanctioned to Adilabad district. Dhanora is one among them by covering (6) Micro watershed villages, the total project area is $4566 \mathrm{Hac}$, Project Cost Rs. 547.92 Lakhs. The sanctioned area of Gunjala micro watershed is $710 \mathrm{Hac}$ with a outlay of Rs. 85.20 Lakhs. Out of which the total expenditure incurred is Rs.39.12 Lakhs and constructed LBS, RFDs, PTs, CDs and Plantation.

\section{METHODOLOGY}

\subsection{Construction of Structures (Engineering)}

1. Mini Percolation tanks (M.P.Ts) - 30 to 40 per water shed in the first and second order streams and Big percolation tanks in $3^{\text {rd }}$ and $4^{\text {th }}$ order streams were constructed.

2. Check dams in the $2^{\text {nd }}$ or $3^{\text {rd }}$ order streams with earthen dam at centre and surplus weir on side - (The earthen bund check dams should not be constructed in the main streams where maximum floods discharges will be very high).

3. Sunken pits in gullies in first and second order streams.

4. M.P.Ts at head of gullies and up stream of sunken pits and drainage line treatment.

5. C.C.Ts strictly along contour, with side slopes for cut section with M.P.Ts at gully junctions.

6. Boundary bunds to be formed with "Boundary Bund" technology. Contour bunds to be formed wherever farmers agree. Contour ploughing in rainfed lands.
7. Diversions drain and sump, for recharging open dug wells.

8. Sub surface dam at the downstream of Watershed.

9. Rubble stone diversion weir on the mainstream, for gravity irrigation.

10. Restoring and desilting very small tanks (kuntas) lying within the watershed.

\subsection{Vegetative}

1. Cover crops in rainfed lands.

2. Tree plantations on all uncultivated lands to develop a 3 tier canopy.

3. Trees on all boundary bunds of rainfed lands, with a small trench on either side.

4. Vegetative cover (agave) for gully slopes.

5. Tree plantation on slopes and banks of gully.

6. Nurseries for fodder, timber, fuelwood and horticulture.

7. Agro-forestry including block plantations, Shelter belts, sand dune stabilization etc.

8. Pasture development either by itself or in conjunction with plantation.

\subsection{General}

Topographic contour surveys (contour interval of $1 \mathrm{~m}$ ), soil classification and land capability analysis will have to be done before starting the works. $R \& D$ on specific technical aspects can be undertaken, as felt necessary.

\subsection{Social and Managerial}

The above structural works are very simple and mostly consist of earthwork excavation. There is no cement - based work, (like concrete, masonry, plastering for check dam etc.) anywhere in the entire watershed. None of the works cost more than Rs. 8,000/- each. Vested interests and local political pressures to execute works, which were existing in some water sheds earlier, are automatically eliminated in this technology, as there is no scope for making money or earning profits in such small works. Again participation is maximum and automatic in this technology, since not more than two farmers are involved in any work. 


\section{RESULTS-OUT COME OF CHECK DAM}

Table 1

\begin{tabular}{|l|l|l|l|l|l|l|}
\hline \multirow{2}{*}{ Farmer details } & \multicolumn{2}{|l|}{$\begin{array}{l}\text { Before Construction of CD - } \\
\text { Jun 2010 to Dec 2010 }\end{array}$} & $\begin{array}{l}\text { After Construction of CD } \\
\text {-Jun 2011 to Mar 2012 }\end{array}$ & \multicolumn{2}{l|}{ Additional yield \& Income } \\
\cline { 2 - 7 } & Cotton & Red gram & Cotton & Red gram & Cotton & Red gram \\
\hline $\begin{array}{l}\text { Jadhav uttham } \\
\text { (5 Acre })\end{array}$ & 7 Qts/Acre & 1.2 Qts/Acre & 11 Qts/Acre & 3 Qts/Acre & 4 Qts/Acre & 1.8 Qts/Acre \\
\hline Rate per Qtl & 4400 & 3500 & 4400 & 3500 & & \\
\hline Total Income & Rs.30800 & Rs.4200 & Rs.48400 & Rs.10500 & Rs.17600 & Rs.6300 \\
\hline Crop Period & June to Dec & June to Dec & $\begin{array}{l}\text { June to } \\
\text { March }\end{array}$ & $\begin{array}{l}\text { June } \\
\text { February }\end{array}$ & & \\
\hline
\end{tabular}

The above table analysis indicates the farmer Jadhav Uttam has an additional income of Rs. 17,600 per Acre in cotton and Rs. 6300 per Acre in Red Gram. The above farmer is cultivating the cotton and Red Gram in 5 Acre of land. The total additional income generated after construction of Check Dam of Rs. 1,19,500/- for the Jadhav Uttam in 2012 Cropping Season.

Table 2:

\begin{tabular}{|c|c|c|c|c|c|c|}
\hline \multirow[t]{2}{*}{ Farmer details } & \multicolumn{2}{|c|}{$\begin{array}{l}\text { Before Construction of CD - } \\
\text { Jun } 2010 \text { to Dec } 2010\end{array}$} & \multicolumn{2}{|c|}{$\begin{array}{l}\text { After Construction of CD -Jun } \\
2011 \text { to Mar } 2012\end{array}$} & \multicolumn{2}{|c|}{ Additional yield \& Income } \\
\hline & Cotton & Red gram & Cotton & Red gram & Cotton & Red gram \\
\hline $\begin{array}{l}\text { Gnansingh } \\
\text { (4 Acre) }\end{array}$ & 6 Qts/Acre & 1.5 Qts/Acre & 10 Qts/Acre & 3 Qts/Acre & 4 Qts/Acre & 1. Qts/Acre \\
\hline Rate per Qtl & 4400 & 3500 & 4400 & 3500 & & \\
\hline Total Income & Rs.26,400 & Rs.5,250 & Rs.44,000 & Rs. 10500 & Rs.17600 & Rs.5250 \\
\hline Crop Period & June to Dec & June to Dec & June to March & $\begin{array}{l}\text { June } \\
\text { February }\end{array}$ & & \\
\hline
\end{tabular}

The above table analysis indicates the farmer Gnan Singh has an additional income of Rs. 17600 per Acre in cotton and Rs. 5,250 per Acre in Red Gram. The above farmer is cultivating the cotton and Red Gram in 4 Acre of land. The total additional income generated after construction of Check Dam of Rs. 91,400/- for the Gnan Singh in 2012 Cropping Season.

Table 3:

\begin{tabular}{|c|c|c|c|c|c|c|}
\hline \multirow[t]{2}{*}{ Farmer details } & \multicolumn{2}{|c|}{$\begin{array}{l}\text { Before Construction of CD } \\
\text {-Jun } 2010 \text { to Dec } 2010\end{array}$} & \multicolumn{2}{|c|}{$\begin{array}{l}\text { After Construction of CD -Jun } \\
2011 \text { to Mar 2012 }\end{array}$} & \multicolumn{2}{|c|}{ Additional yield \& Income } \\
\hline & Cotton & Red gram & Cotton & Red gram & Cotton & Red gram \\
\hline $\begin{array}{l}\text { Amber Singh } \\
\text { (3 Acre) }\end{array}$ & 8 Qts/Acre & 2 Qts/Acre & $11 \mathrm{Qts} / A c r e$ & 3 Qts/Acre & 3 Qts/Acre & 1. Qts/Acre \\
\hline Rate per Qtl & 4400 & 3500 & 4400 & 3500 & & \\
\hline Total Income & Rs.35,200/- & Rs.7000/- & Rs.55,000/- & Rs.10500/- & Rs.13200/- & Rs.3500/- \\
\hline Crop Period & June to Dec & June to Dec & June to March & June to February & & \\
\hline
\end{tabular}

The above table analysis indicates the farmer Amber Singh has an additional income of Rs. 13200 per Acre in cotton and Rs. 3,500 per Acre in Red Gram. The above farmer is cultivating the cotton and Red Gram in $\mathbf{3}$ Acre of land. The total additional income generated after construction of Check Dam of Rs. 50,100/- for the Amber Singh in 2012 Cropping Season.

Table 4:

\begin{tabular}{|l|l|l|l|l|l|l|}
\hline \multirow{2}{*}{ Farmer details } & \multicolumn{2}{|l|}{$\begin{array}{l}\text { Before Construction of CD - } \\
\text { Jun 2010 to Dec 2010 }\end{array}$} & $\begin{array}{l}\text { After Construction of CD -Jun } \\
\mathbf{2 0 1 1} \text { to Mar 2012 }\end{array}$ & \multicolumn{2}{|l|}{ Additional yield \& Income } \\
\cline { 2 - 7 } & Cotton & Red gram & Cotton & Red gram & Cotton & Red gram \\
\hline $\begin{array}{l}\text { Mesram Eshwar } \\
\text { (6 Acres) }\end{array}$ & 7 Qts/Acre & 1.5 Qts/Acre & 11 Qts/Acre & 3 Qts/Acre & 3 Qts/Acre & 1. Qts/Acre \\
\hline
\end{tabular}




\begin{tabular}{|l|l|l|l|l|l|l|}
\hline Rate per Qtl & 4400 & 3500 & 4400 & 3500 & & \\
\hline Total Income & Rs.30,800/- & Rs.5250/- & Rs.55,000/- & Rs.10500/- & Rs.24200/- & Rs.3500/- \\
\hline Crop Period & June to Dec & June to Dec & $\begin{array}{l}\text { June to } \\
\text { March }\end{array}$ & June to February & & \\
\hline
\end{tabular}

The above table analysis indicates the farmer Mesram Eshwar has an additional income of Rs. 24200 per Acre in cotton and Rs. 3,500 per Acre in Red Gram. The above farmer is cultivating the cotton and Red Gram in 6 Acre of land. The total additional income generated after construction of Check Dam of Rs. 1,66,200/- for the Mesram Eshwar in 2012 Cropping Season.

Table 5

\begin{tabular}{|l|l|l|l|l|l|l|}
\hline \multirow{2}{*}{ Farmer details } & \multicolumn{2}{|l|}{$\begin{array}{l}\text { Before Construction of CD -Jun } \\
\mathbf{2 0 1 0} \text { to Dec 2010 }\end{array}$} & $\begin{array}{l}\text { After Construction of CD } \\
- \text { Jun 2011 to Mar 2012 }\end{array}$ & \multicolumn{2}{l|}{ Additional yield \& Income } \\
\cline { 2 - 7 } & Cotton & Red gram & Cotton & Red gram & Cotton & Red gram \\
\hline $\begin{array}{l}\text { Somula } \\
\text { Tukaram } \\
(2 \text { Acres) }\end{array}$ & 5 Qts/Acre & 1.5 Qts/Acre & 8 Qts/Acre & 3 Qts/Acre & 3 Qts/Acre & 1.5 Qts/Acre \\
\hline Rate per Qtl & 4400 & 3500 & 4400 & 3500 & & Rs.5250 \\
\hline Total Income & Rs.22,000 & Rs.5250 & Rs.35,200 & Rs. 10500 & Rs. 13200 & \\
\hline Crop Period & June to Dec & June to Dec & $\begin{array}{l}\text { June to } \\
\text { March }\end{array}$ & $\begin{array}{l}\text { June to } \\
\text { February }\end{array}$ & & \\
\hline
\end{tabular}

The above table analysis indicates the farmer Somula Tukaram has an additional income of Rs. 13200 per Acre in cotton and Rs. 5250 per Acre in Red Gram. The above farmer is cultivating the cotton and Red Gram in 2 Acre of land. The total additional income generated after construction of Check Dam of Rs. 36,900/- for the Somula Tukaram in 2012 Cropping Season.

Table 6:

\begin{tabular}{|c|c|c|c|c|c|c|}
\hline \multirow{2}{*}{$\begin{array}{l}\text { Farmer } \\
\text { details }\end{array}$} & \multicolumn{2}{|c|}{$\begin{array}{l}\text { Before Construction of CD - } \\
\text { Jun } 2010 \text { to Dec } 2010\end{array}$} & \multicolumn{2}{|c|}{$\begin{array}{l}\text { After Construction of CD - } \\
\text { Jun } 2011 \text { to Mar } 2012\end{array}$} & \multicolumn{2}{|c|}{ Additional yield \& Income } \\
\hline & Cotton & Red gram & Cotton & Red gram & Cotton & Red gram \\
\hline $\begin{array}{l}\text { Rathod } \\
\text { Dulsingh } \\
\text { (3 Acres) }\end{array}$ & 6 Qts/Acre & 1 Qts/Acre & 8 Qts/Acre & 3 Qts/Acre & 2 Qts/Acre & 2 Qts/Acre \\
\hline Rate per Qtl & 4400 & 3500 & 4400 & 3500 & & \\
\hline Total Income & Rs. 26,400 & Rs. 3500 & Rs. 35,200 & Rs. 10500 & Rs. 8800 & Rs.7000 \\
\hline Period & June to Dec & June to Dec & $\begin{array}{l}\text { June to } \\
\text { March }\end{array}$ & $\begin{array}{l}\text { June to } \\
\text { February }\end{array}$ & & \\
\hline
\end{tabular}

The above table analysis indicates the farmer Rathod Dulsingh has an additional income of Rs. 8800 per Acre in cotton and Rs. 7000 per Acre in Red Gram. The above farmer is cultivating the cotton and Red Gram in 3 Acre of land. The total additional income generated after construction of Check Dam of Rs. 47,400/- for the Rathod Dulsingh in 2012 Cropping Season. .

Table 7:

\begin{tabular}{|l|l|l|l|l|l|l|}
\hline \multirow{2}{*}{ Farmer details } & \multicolumn{2}{|l|}{$\begin{array}{l}\text { Before Construction of CD } \\
\text {-Jun 2010 to Dec 2010 }\end{array}$} & $\begin{array}{l}\text { After Construction of CD - } \\
\text { Jun 2011 to Mar 2012 }\end{array}$ & \multicolumn{2}{l|}{ Additional yield \& Income } \\
\cline { 2 - 7 } & Cotton & Red gram & Cotton & Red gram & Cotton & Red gram \\
\hline Jadhav Ganesh & 7 Qts/Acre & 1.2 Qts/Acre & 11 Qts/Acre & 3 Qts/Acre & 4 Qts/Acre & 1.8 Qts/Acre \\
\hline
\end{tabular}




\begin{tabular}{|l|l|l|l|l|l|l|}
\hline (5 Acres) & & & & & \\
\hline Rate per Qtl & 4400 & 3500 & 4400 & 3500 & & \\
\hline Total Income & Rs.30800 & Rs.4200 & Rs.48400 & Rs.10500 & Rs.17600 & Rs.6300 \\
\hline Period & $\begin{array}{l}\text { June to } \\
\text { Dec }\end{array}$ & June to Dec & June to March & $\begin{array}{l}\text { June February } \\
\text { Fe }\end{array}$ & \\
\hline
\end{tabular}

The above table analysis indicts the farmer Jadhav Ganesh has an additional income of Rs. 17600 per Acre in cotton and Rs. 6300 per Acre in Red Gram. The above farmer is cultivating the cotton and Red Gram in 5 Acre of land. The total additional income generated after construction of Check Dam of Rs. 1,19,500/- for the Jadhav Ganesh in 2012 Cropping Season. .

\section{CONCLUSION}

1. The major objective of the IWMP programme is to improve the ground water level and the ground water level is improved by constructing the water harvesting structure like Mini Percolation tank, Percolation tank and Check dams. At Gunjala watershed area and Ankoli water shed area of Adilabad District.

2. Soil erosion is controlled and soil moisture conservation is improved by constructing of gully control works and thus improved the productivity of land and reduced the cost of cultivation and quality of produles also improved.

3. By improving the ground water level and reducing the erosion control will boost the economic condition of the poor farmer trough improvement of agriculture production to words integrated approach in IWMP programme.

4. Total Additional income generated for Seven farmers of Rs. 6, 31000/- in 2011-2012 Cropping Season with construction of Check Dams of Rs.3,24000/- an additional average income per Acre to the farmer is of Rs. 22,500/- and a series of 8 Nos. check dams are constructed on single $3^{\text {rd }}$ order stream which flows Across the 6 Grama Panchayats from ridge to valley. There are 90 farmers cultivating 168 Acre of land who are benefited by getting an additional income of Rs.37,80,000/-

\section{DISCUSSION}

It is also necessary to increase the recharge to ground water in rural as well as urban areas. Land use in the urban areas is different from that of the rural areas (agriculture, crops) Most of the urban area would comprise paved roads, built up areas, open grounds (play grounds, parks etc.,) The amount of deep percolation taking place in the rural area predominantly with an agricultural covers for the land, is appreciable. Hence, we can make use of the structures like percolation tanks, contour trenches, soak pits etc which can increase the ground water recharge. The above idea of providing water storage structures can also be implied in forest areas.

\section{REFERENCES}

[1] Innovative Participatory Technologies for Watershed Development and Drought Prone Areas of India (four water concept) by - Sri. T. Hanumanth Rao Former Engineer - in - Chief, Irrigation, Andhra Pradesh.

[2] Technical Manual of Rural Development Department on Watersheds by SLNA

[3] www.google.com and www.iwmp.gov.telangana.in

[4] Detailed Project Report of Ankoli Megh watershed and Gunjala Watersheds 